[Agr. Biol. Chem., Vol. 30, No. 5, p. 519 521, 1966]

\title{
A Method of Fractionation of Bacterial Cytoplasmic Membrane*
}

Sir:

In 1953, Weibull ${ }^{1)}$ prepared the cytoplasmic membrane fraction "Ghost" from protoplasts by the osmotic lysis.

But the "Ghost" contains many cytoplasmic materials besides the membrane itself. This fact was proved not only by the chemical analysis but also by the electron microscopic observation.

We made an effort to isolate the real cytoplasmic membrane from the "Ghost" of Weibull. And it was found that, when sufficient dialysis was performed against distilled water, a large part of the "Ghost" become soluble in dilute alkali and can be separated to several fractions by centrifugation.

In this communication, a method of the fractionation of the "Ghost" to obtain the pure membrane material is described.

Bacillus megaterium strain KM grown at $30^{\circ} \mathrm{C}$ for 15 hours in a nutrient medium was collected by centrifugation, suspended in lysozyme solution $\left(0.5 \mathrm{M}\right.$ sucrose, $0.005 \mathrm{M} \mathrm{MgCl}_{2}$, $60 \mu \mathrm{g} / \mathrm{ml}$ lysozyme in $0.05 \mathrm{M}$ phosphate buffer, $\mathrm{pH} \mathrm{7.0)}$ at a concentration of $10 \mathrm{mg}$ cell $/ \mathrm{ml}$, and incubated at $30^{\circ} \mathrm{C}$. Protoplast formation was completed within about 30 minutes.

Preparation of the cytoplasmic membrane fraction "Ghost" was obtained from the protoplasts according to the method of Weibull.". The normal yield was 80 to $85 \mathrm{mg}$ per $\mathrm{g}$ of cells, which is almost equal to the Weibull's data.

The "Ghost" was a little soluble in sodium dodecyl sulfate or sodium deoxycholate, but the removal of these detergents is not easy. But by enough dialysis against distilled water,

- This report was partiallv presented at the meetings of Agricultural Chemical Society of Japan (Tokyo, April 25, 1965) and Japanese Biochemical Society (Fukuoka, October 20. 1965).

1) C. Weibull, J. Bacteriol., 66, 696 (1953).

2) C. Weibull and L. Bergström, Biochim. Biophys. Acta, 30, 340 (1958). we could find most part of the "Ghost" becomes soluble in dilute alkali solution as shown below.

The procedure of fractionation of the "Ghost" is as follows:

TABLE I. AMOUNT OF Various Substance IN EACH FraCtion of THE CYTOPLASMIC MEMBRANE OF Bacillus megaterium STRAIN KM.

Assay substance "Ghost" Frac.1 Frac.2 Frac.3 Frac.4

$\begin{array}{lrrrrr}\text { 1. Dry weight (g) } & 12.43 & 1.74 & 3.72 & 4.51 & 2.50 \\ \text { 2. Nitrogen } & 10.70 & 4.15 & 9.35 & 11.25 & 8.75 \\ \text { 3. Protein } & 65.60 & 11.50 & 58.10 & 72.30 & 50.63 \\ \text { 4. Lipid } & 20.05 & 15.35 & 27.11 & 21.30 & 15.65 \\ \text { 5. Hexose } & 11.05 & 54.53 & 4.35 & 2.25 & 5.32 \\ \text { 6. 3+4+5 } & 96.70 & 83.27 & 89.56 & 96.15 & 71.60 \\ \text { 7. RNA } & 1.05 & 0.11 & 0.73 & 0.62 & 2.35 \\ \text { 8. Phosphorus } & 1.15 & 1.03 & 1.10 & 1.51 & 0.73 \\ \text { 9. PHB* } & 5.15 & 0.10 & 2.10 & 1.00 & 2.50 \\ \text { 10. Enzymes** } & \text { \#\# } & - & \text { \# } & + & +\end{array}$

These figures show percentage in each fraction.

* Poly- $\beta$-hydroxybutyric acid.

** Esterase, phosphatase, ATPase, DPNH oxidase and succinic oxidase were estimated in each fraction, and their localization is roughly shown in this table.

The protein was estimated by the weight of the material insoluble in h.t trichloroacetic acid after extraction of the lipids. This was checked by determining the protein according to Lowry et al., ${ }^{3}$ ' insoluble protein samples being dissolved in $\mathrm{N} \cdot \mathrm{NaOH}$.

The lipid was determined by the loss in weight of a sample after extraction by boiling for $30 \mathrm{~min}$ in chloroformethanol $(1: 1, y / v)$. The extract was then evaporated to dryness and the residue was weighted to check the first estimate. The sugars were determined after hydrolysis and passing through Dowex-50 column by the anthrone method as described by Scott and Melvin." RNA was estimated by the orcinol method.5) The dry weight was determined after drying the sample at $100^{\circ} \mathrm{C}$ for $24 \mathrm{hr}$. PHB was determined by the method of Ralph et al. ${ }^{01}$ and phosphorus by the method of Fiske and Subbarow ${ }^{7)}$ after digestion with conc. $\mathrm{H}_{2} \mathrm{SO}_{4}$. The nitrogen was determined by the microKjeldahl method ${ }^{8}$

3) O. H. Lowry, N. J. Rosebrough, A. L. Farr and R. J. Randall, J. Biol. Chern., 193, 265 (1451).

4) T. A. Scott and E. H. Melvin, Anal. Chem., 25, 1656 (1953).

5) G. Ceriotti, J. Biol. Chem., 214, 59 (1955)

6) A. Ralph, R. Slepecky and J.H. Law, Anal. Chem, 32, $1697(1960)$.

7) C. H. Fiske and Y. Subbarow, J. Biol. Chem., 66, 375 (1925).

8) T.S. Ma and G. Zuazaga, Ind. Eng. Chem., 14, 280 (1942). 
A suspension containing $12 \mathrm{~g}$ of the "Ghost" in $300 \mathrm{ml}$ distilled water was dialyzed against $200 \mathrm{vol}$. of distilled water at $5^{\circ} \mathrm{C}$ for 48 hours, changing the distlled water every 12 hours.

To the dialyzed suspension $1 / 50 \mathrm{~N}-\mathrm{NaOH}$ was added to bring $\mathrm{pH}$ 8.0. After stirring for 20 minutes at $5^{\circ} \mathrm{C}$ the suspension was centrifuged at $5,000 \times \mathrm{g}$ for 20 minutes, and the heavy dark-gray precipitate was separated (Frac. 1). The supernatant was recentrifuged at higher speed of $105,000 \times \mathrm{g}$ for 30 minutes and brown precipitate was obtained (Frac. 2).

The $\mathrm{pH}$ of the supernatant was adjusted to 6.0 with $\mathrm{N} / 50 \mathrm{HCl}$, and the yellowish precipitate thus formed was centrifuged at $10,000 \times \mathrm{g}$ for 10 minutes at $5^{\circ} \mathrm{C}$ (Frac. 3), and the supernatant (Frac. 4) was separated from the precipitate.

The yield and the chemical composition of the each fraction were examined in details. Table I shows the results of this experiment. Frac. 1 consisted largely of carbohydrate and contained in addition smaller amounts of lipid and protein, with little RNA.

The yields of Frac. 2 and 3 were approximately equal and they were made up mainly of protein, lipid and sugar with a little or no RNA. But their ratios of lipid and protein differed from each other; in Frac. 2 a large amount of lipid was observed: amounted to $45 \%$ of protein; whereas it was only $28 \%$ of protein content in Frac. 3.

Poly- $\beta$-hydroxybutyric acid and enzymes such as esterase or phosphatase were mainly seen in Frac. 2.

Frac. 2 and 3 consisted of ultracentrifugally homogeneous substances having sedimentation constants of 1 and 3 Svedberg units, respectively.

Under the electron microscope, the "Ghost" apparently released the cytoplasmic contents, but many small dense particles (about $100 \AA$ in diameter) attached to the membrane structure (Plate 1 a).

On the other hand, the Frac. 2 was made up only of a membrane structure which looks
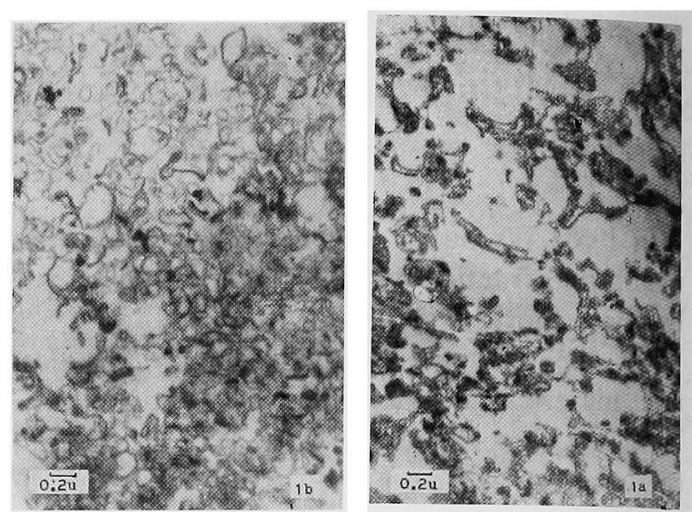

Plate 1. Electron Micrographs of the Cytoplasmic Membrane of $B$. megaterium Strain KM.

a) "Ghost" prepared according to the method of Weibull.

b) Frac. 2 prepared by fractionating the "Ghost" as described in the text.

Samples were fixed with $1 \%$ osmic acid at $5^{\circ} \mathrm{C}$ for 15 hours, dehydrated with Araldite and embedded in mixture of 1 part of methyl and 9 parts of butyl methacrylate at $50^{\circ} \mathrm{C}$ for 72 hours.

(Hitachi Model HU-11B electroscope).

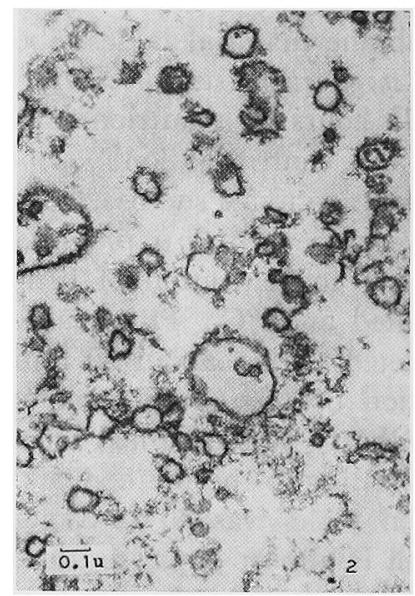

Plate 2. Electron Micrographs of Membrane Structure Reconstituted from "Frac. 2"

The method and condition as in Plate 1.

like balloons of $0.5 \mu$ in diameter. No $100 \AA$ particles are visible in this fraction (Plate $1 \mathrm{~b}$ ).

Recently, it was found that the Frac. 2 could be solubilized in formic acid and was no more precipitated by centrifugation at $105,000 \times \mathrm{g}$. 
By adding ether to this solution or dialyzing it against distilled water, precipitates were formed. These precipitates are amorphous bodies under electron microscope. But it is very interesting that when dialyzed against $10^{-3} \mathrm{M} \mathrm{MgCl}_{2}$ or $\mathrm{CaCl}_{2}$, the precipitates change their morphological structures from amorphous body to balloon form.

Razin et al. "' reported that the cell membrane of Mycoplasma laidlawii was dissolved by sodium lauryl sulfate, and that dialysis of the solution formed brought about reaggrega- tion to from membrane-like structures in presence of di- or multivalent cations. A similar phenomena was also observed in the formic acid solution of the pure membrane (Frac. 2) obtained by our own method from the "Ghost" of Bacillus me gaterium.

Tsutomu Yamaguch Gakuzo Tamura

Kei Arima

Department of Agricultural Chemistry, The University of Tokyo, Tokyo. 